\title{
INOVASI BERBASIS MASYARAKAT DESA TANGGUH BENCANA (DESTANA)
}

\author{
Fathinah Ranggauni HARDY1, Rafiah Maharani PULUNGAN², Putri PERMATASARI³ \\ Universitas Pembangunan Nasional Veteran Jakarta \\ Email: fathinahranggaunihardy@gmail.com
}

\begin{abstract}
ABSTRAK
Kabupaten Lebak, Provinsi Banten merupakan salah satu daerah di Indonesia yang masif terjadi gempa bumi selama 1 tahun terakhir. BNPB telah melaporkan terjadinya gempa bumi tektonik dengan kekuatan $M=6.1$ SR pada tanggal 23 Januari 2018 berlokasi di laut pada jarak $43 \mathrm{~km}$ arah selatan Kabupaten Lebakpada kedalaman $61 \mathrm{~km}$. Kecamatan Cikulur salah satu kecamatan di Kabupaten Lebak memiliki kerusakan yang parah dan mengalami kerugian secara fisik yaitu 291 rumah rusak berat (RB), 575 rusak sedang RS), dan 1.894 rusak ringan (RR) (BNPB, 2018) dan secara non fisik banyak warga yang mengalami trauma akibat kejadian gempa tersebut. Kecamatan-kecamatan di Kabupaten Lebak belum memiliki upaya manajemen bencana berbasis masyarakat yang optimal, misalnya belum ada Desa Tangguh Bencana sesuai 20 Indikator Desa Tangguh Bencana. Berdasarkan dari permasalahan tersebut, tim pengabdian kepada masyarakat bergerak untuk membentuk inovasi berbasis masyarakat berupa Desa Tangguh Bencana di Kabupaten Lebak yang inisiasi awal di Desa Anggalan, Kecamatan Cikulur. Tujuan dari kegiatan adalah untuk membentuk Desa Tangguh Bencana di Kabupaten Lebak berbasis masyarakat agar siap dalam menghadapi bencana.Kegiatan yang dilakukan adalah pembentukan Desa Tangguh Bencana adalah Penilaian Risiko, Perencanaan Penanggulangan Bencana (PB) di Desa, Pembentukan Forum PB di Peningkatan Kapasitas Warga dan Aparat dalam PB melalui Pelatihan Kebencanaan pada warga dan perangkat desa, Pemaduan PB ke dalam Rencana Pembangunan Desa dan Legalisasi Desa Tangguh Bencana. Target Luaran dari PKM ini adalah terbentuknya Desa Tangguh Bencana.
\end{abstract}

Kata Kunci: Desa, Tangguh, Bencana, Inovasi, Masyarakat 


\section{PENDAHULUAN}

Istilah bencana biasanya mengacu pada keadaan alami, misalnya angin ribut atau gempa bumi yang dikaitkan dengan efek kerusakan yang ditimbulkannya misalnya hilangnya kehidupan atau kerusakan bangunan. Bahaya mengacu pada kejadian alami dan kerentanan mengacu pada kelemahan suatu populasi atau sistem terhadap pengaruh dari bahaya tersebut (Pan American Health Organization, 2000).

Bencana alam merupakan peristiwa yang luar biasa dan terjadi di berbagai belahan dunia. Dampak yang diakibatkan oleh bencana alam sungguh luar biasa pula bagi yang mengalaminya. Bahkan, bencana alam tertentu dapat menimbulkan korban jiwa dalam jumlah yang tidak sedikit baik korban cedera maupun meninggal dunia. Indonesia merupakan salah satu negara yang rawan akan bencana alam. Berbagai bencana alam telah terjadi di berbagai wilayah di Indonesia dari tahun ketahun dan korbannyapun tidak sedikit. Bencana alam di Indonesia meliputi tsunami, gunung meletus, gempa bumi, banjir, tanah longsor, kebakaran hutan, abrasi pantai dan erosi.

Bencana alam tidak hanya menimbulkan korban fisik, akan tetapi berdampak juga pada gangguan fisikologis dan trauma yang mendalam. Hilangnya harta benda dan nyawa dari orang-orang yang dicintainya, membuat sebagian korban mengalami stress dan gangguan kejiwaan. Mitigasi dan Kesiapsiagaan merupakan salah satu tahapan yang sangat vital dalam manajemen bencana. UndangUndang No. 24 Tahun 2007 tentang Penanggulangan Bencana mengamanatkan untuk melakukan upaya penanggulangan bencana secara tepat, cepat, berdasarkan prioritas, koordinasi, keterpaduan, berdaya guna, berhasil guna, transparansi, akuntabilitas, kemitraan dan pemberdayaan.

Negara Kesatuan Republik Indonesia (NKRI) secara keseluruhan berada pada posisi rawan bencana, baik bencana alam geologis maupun bencana alam yang diakibatkan ulah manusia. Selama 5 tahun terakhir telah terjadi bencana alam sebanyak 158.238 kasus meliputi bencana gunung berapi, banjir, tanah longsor, kekeringan, angin puting beliung, gempa bumi, kebakaran hutan, kebakan pemukiman, dan bencana alam lainnya, diantara bencana alam yang terjadi di Indonesia (BNPB, 2014).

Posisi geografis kepulauan Indonesia berada pada pertemuan tiga lempeng tektonik raksasa (Eruasia, India Australia dan Pasifik) dan terletak diantara Benua Asia dan Australia dan Samudera Hindia dan Pasifik serta terdiri dari \pm 17.000 pulau yang sebagian besar berhadapan dengan laut lepas dengan garis pantai lebih dari $81.000 \mathrm{~km}$. Posisi geografis tersebut, menyebabkan Indonesia rentan terhadap letusan gunung berapi dan gempa bumi, terpengaruh gelombang pasang hingga tsunami serta cuaca ekstrim yang berpotensi menimbulkan banjir dan tanah longsor serta kekeringan. Berdasarkan sejarah kebencanaan, terhimpun hampir semua bencana alam di dunia telah terjadi di Indonesia dan setiap terjadi bencana alam, setiap kali pula kejadian tersebut menimbulkan korban jiwa (Hendrianto, 2012).

Dampak kejadian bencana menyentuh seluruh bidang, baik ekonomi, sosial-budaya, politik, namun yang paling utama dirasakan adalah bidang kesehatan. Disadari bahwa dengan adanya kejadian bencana, maka selalu timbul wabah penyakit yang merupakan dampak dari kondisi lingkungan yang rusak, sanitasi yang kurang, daya tahan tubuh manusia menurun drastis dan kurangnya sarana obat-obatan. Pelayanan kesehatan pada saat bencana merupakan faktor yang sangat penting untuk mencegah terjadinya kematian, kecacatan dan kejadian penyakit, karena bencana merupakan suatu kejadian yang tidak diinginkan dan biasanya terjadi secara mendadak serta disertai jatuhnya korban. Keadaan ini bila tidak ditangani secara cepat dan tepat dapat menghambat, mengganggu, serta menimbulkan kerugian bagi kehidupan masyarakat.

Upaya penanggulangan krisis akibat bencana merupakan rangkaian kegiatan yang dimulai sejak sebelum terjadinya wabah dan bencana yang dilakukan melalui kegiatan pencegahan, mitigasi (pelunakan/penjinakan dampak) dan kesiapsiagaan dalam menghadapi wabah dan bencana. Kegiatan yang dilakukan pada saat terjadinya wabah danbencana berupa kegiatan tanggap darurat dan selanjutnya pada saat setelah terjadinya wabah dan bencana berupa kegiatan pemulihan/rehabilitasi dan rekonstruksi. 
Untuk itu penanggulangan krisis akibat wabah dan bencana harus mempunyai suatu pemahaman permasalahan dan penyelesaian secara komprehensif, serta terkoordinasi secara lintas program dan lintas sektor. Sebagaimana kebijakan dan strategi nasional saat ini, upaya penanggulangan bencana lebih dititikberatkan pada upaya sebelum terjadinya bencana, yang salah satunya adalah kegiatan kesiapsiagaan. Menurut UU No. 24 tahun 2007 tentang Penanggulangan Bencana, kesiapsiagaan merupakan serangkaian kegiatan yang dilakukan untuk mengantisipasi bencana melalui pengorganisasian serta melalui langkah yang tepat guna dan berdaya guna (pelatihan, gladi, penyiapan sarana dan prasarana, SDM, logistik dan pembiayaan). Dengan kesiapsiagaan yang tepat diharapkan upaya penanggulangan dapat lebih cepat dan tepat sehingga dapat meminimalisir jumlah korban dan kerusakan.

Pada penanggulangan bencana telah terjadi perubahan paradigma, dari penanganan bencana berubah menjadi pengurangan risiko bencana, artinya saat ini penyelenggaraan penanggulangan bencana lebih menitikberatkan pada tahap pra bencana daripada tahap tanggap darurat (Raharja, Eddie, 2009). Kesiapsiagaan terhadap bencana ini harus dapat diantisipasi baik oleh unsur pemerintah, swasta maupun masyarakat. Dalam kesiapsiagaan krisis akibat bencana oleh pemerintah diperlukan upaya-upaya, mulai dari pengembangan peraturan peraturan, penyiapan program, pendanaan dan pengembangan jejaring lembaga atau organisasi siaga bencana.

Kabupaten Lebak, Provinsi Banten merupakan salah satu daerah di Indonesia yang telah masif terjadi gempa bumi selama 1 tahun terakhir. BNPB telah melaporkan terjadinya gempa bumi tektonik dengan kekuatan $M=6.1$ SR yang paling besar terjadi pada hari Selasa, 23 Januari 2018, pukul 13:34:53 WIB, wilayah Samudera Hindia, Selatan Jawa. Gempa tersebut terjadi dengan koordinat episenter pada 7,23 LS dan 105,9 BT, atau tepatnya berlokasi di laut pada jarak $43 \mathrm{~km}$ arah selatan Desa Cilangkahan, Kecamatan Malingping, Kabupaten Lebak, Provinsi Banten pada kedalaman $61 \mathrm{~km}$. Gempa ini tidak berpotensi tsunami. Pusat gempa yang berada di darat atau dekat pantai menyebabkan guncangan keras dirasakan oleh masyarakat (BNPB, 2018).

Dampak gempa bumi yang digambarkan oleh Peta tingkat guncangan (shakemap) BMKG menunjukkan bahwa dampak gempabumi berupa guncangan dirasakan di daerah Jakarta, Tangerang Selatan, Bogor antara IV-V MMI. Laporan dari BPBD dan Pusdalops BNPB menyebutkan bahwa gempa dirasakan sangat kuat di Provinsi Banten dan menyebabkan kepanikan. Sampai saat ini sudah tercatat sudah ada 53 kali gempa susulan dengan magnitudo yang lebih kecil. Data terkini BNPB sebelumnya menyatakan, gempa yang paling besar telah menyebabkan 2.760 rumah rusak. Jumlah rumah yang rusak itu datanya masih mungkin bertambah. Hal ini mengingat Badan Penanggulangan Bencana Daerah (BPBD) masih terus melakukan pendataan. Sebanyak 2.760 unit rumah rusak itu rinciannya 291 rumah rusak berat (RB), 575 rusak sedang RS), dan 1.894 rusak ringan (RR). Kabupaten Lebak adalah daerah yang paling banyak terdapat kerusakan bangunan rumah karena posisinya berdekatan dengan pusat gempa. Selain itu juga terdapat kerusakan bangunan lainnya meliputi tujuh unit fasilitas peribadatan, dua unit fasilitas kesehatan, 17 unit fasilitas pendidikan, enam unit kantor atau gedung pemerintahan, dan 63 unit fasilitas umum. BNPB menaksir kerugian mencapai ratusan milyar rupiah (BNPB, 2018). 


\section{METODE}

Berikut metode pendekatan berbagai kegiatan

1. Bersama dengan perangkat desa melakukan Penilaian Risiko Bencana melalui tiga komponen, yaitu penilaian atau pengkajian ancaman, kerentanan dan kapasitas/kemampuan. Ada beberapa perangkat yang dapat digunakan untuk melakukan pengkajian risiko, seperti misalkan HVCA (Hazard, Vulnerability and Capacity Assessment).

2. Bersama dengan perangkat desa melakukan Perencanaan Penanggulangan Bencana (PB) di Desa, melalui penyusunan rencana kegiatan penanggulangan bencana. Metode yang digunakan adalah Focus Group Discussion (FGD) bersama dengan perangkat desa yaitu, Kepala Desa, Puskesmas, Kepala RW dan RT.

3. Bersama dengan perangkat desa membentuk Forum Penanggulangan Bencana. Metode yang digunakan adalah Focus Group Discussion (FGD) bersama dengan perangkat desa yaitu, Kepala Desa, Puskesmas, Kepala RW dan RT.

4. Peningkatan Kapasitas Warga dan Aparat dalam Penanggulangan Bencana melalui Pelatihan Kebencanaan pada warga dan perangkat desa. Metode yang digunakan adalah melalui Seminar dan Simulasi Kebencanaan.

5. Musyawarah dengan perangkat desa melakukan Pemaduan Penanggulangan Bencana kedalam Rencana Pembangunan Desa. Metode yang digunakan adalah Musyawarah Rencana Pembangunan bersama dengan perangkat desa yaitu, Kepala Desa, Puskesmas, Kepala RW dan RT.

6. Legalisasi Desa Tangguh Bencana.

\section{HASIL}

Adapun garis besar hasil pelaksanaan kegiatan adalah sebagai berikut:

1. Langkah awal kegiatan yaitu penyampaian kegiatan kepada Kepala Puskesmas Cikulur tentang agenda pengabdian masyarakat yang akan dilaksanakan di Kecamatan Cikulur. Kegiatan pengabdian masyarakat yaitu tentang Desa Tangguh Bencana. Puskesmas Kecamatan Cikulur sudah mempunyai struktur organisasi yaitu Tim Gerak Cepat (TGC) yang sudah dipersiapkan untuk menanggulangi bencana.

2. Sosialisasi tentang tanggap darurat bencana kepada tenaga Puskesmas pada Kamis, 19 September 2019 yang hadir sebanyak 35 orang petugas Puskesmas meliputi tenaga medis, non medis, dan tenaga non kesehatan serta bidan desa yang bertugas di Puskesmas Cikulur.

3. Sosialisasi tentang tanggap darurat bencana kepada kader masyarakat pada Jumat, 20 September 2019 yang hadir sebanyak 40 orang meliputi tiga pos kader masyarakat di Desa Anggalan, Kecamatan Cikulur.

\section{PEMBAHASAN}

Peningkatan Kapasitas Warga dan Aparat dalam Penanggulangan Bencana melalui Pelatihan Kebencanaan pada warga dan perangkat desa, Pengembangan Desa/Kelurahan Tangguh Bencana dapat terlaksana dengan baik, kapasitas masyarakat dan aparat pemerintah desa-kelurahan dalam isuke organisasian dan pengurangan risiko bencana perlu ditingkatkan.

Penguatan kapasitas dalam isuke organisasian akan diberikan dalam kerjasama dengan lembaga swadaya masyarakat dan/atau perguruan tinggi melalu ilokakarya atau lokalatih di lapangan dalam topik- 
topik seperti pengorganisasian masyarakat, kepemimpinan, manajemen organisasi masyarakat, dan topiktopik terkait lainnya. Peningkatan kapasitas dalam isu PRB akan meliputi pelatihan-pelatihan dalam Pemetaan Ancaman, HVCA atau Penilaian Ancaman, Kerantanan dan Kapasitas PMI, metode-metode PRA (Participatory Rural Appraisal) atau Penilaian Pedesaan Partisipatif, dan metode-metode serupa lainnya yang dibutuhkan. Peningkatan kapasitas juga akan dilakukan melalui penyediaan peralatan dan perangkat-perangkat sistem peringatan dini dan kesiapsiagaan bencana yang terjangkau dalam konteks program.

Musyawarah dengan perangkat desa melakukan Pemaduan Penanggulangan Bencanake dalam Rencana Pembangunan Desa Rencana Penanggulangan Bencana Desa/Kelurahan (RPB Des/Kel) program diharapkan juga mendorong pemaduan PRB kedalam Rencana Pembangunan Desa. Bila berdiri sendiri, RPB kemungkinan sulit untuk mendapatkan pendanaan, karena harus bersaing dengan programprogram pembangunan desa lainnya. Oleh karena itu, selain menyusun RPB Des/Kel, Forum PRB Desa diharapkan juga mendorong masuknya aspek-aspek dalam RPB ke dalam Rencana Pembangunan Jangka Menengah Desa (RPJMDes), sehingga RPJMDes juga mengandung pendekatan pengurangan risiko bencana. Dengan masuknya aspek-aspek PRB kedalam RPJMDes, yang akan dilegalisasi dengan Peraturan Desa, program-program PRB akan mendapat jaminan pendanaan yang lebih kuat. Untuk kelurahan hal serupa juga dapat diterapkan, yakni memadukan program-program PRB kedalam perencanaan di kecamatan.

\section{KESIMPULAN}

1. Bersama dengan perangkat desa melakukan Penilaian Risiko Bencana melalui tiga komponen, yaitu penilaian atau pengkajian ancaman, kerentanan dan kapasitas/kemampuan. Ada beberapa perangkat yang dapat digunakan untuk melakukan pengkajian risiko, seperti misalkan HVCA (Hazard, Vulnerability and Capacity Assessment).

2. Bersama dengan perangkat desa melakukan Perencanaan Penanggulangan Bencana (PB) di Desa, melalui penyusunan rencana kegiatan penanggulangan bencana. Metode yang digunakan adalah Focus Group Discussion (FGD) bersama dengan perangkat desa yaitu, Kepala Desa, Puskesmas, Kepala RW dan RT.

3. Bersama dengan perangkat desa membentuk Forum Penanggulangan Bencana. Metode yang digunakan adalah Focus Group Discussion (FGD) bersama dengan perangkat desa yaitu, Kepala Desa, Puskesmas, Kepala RW dan RT.

4. Peningkatan Kapasitas Warga dan Aparat dalam Penanggulangan Bencana melalui Pelatihan Kebencanaan pada warga dan perangkat desa. Metode yang digunakan adalah melalui Seminar dan Simulasi Kebencanaan.

5. Musyawarah dengan perangkat desa melakukan Pemaduan Penanggulangan Bencana kedalam Rencana Pembangunan Desa. Metode yang digunakan adalah Musyawarah Rencana Pembangunan bersama dengan perangkat desa yaitu, Kepala Desa, Puskesmas, Kepala RW dan RT.

6. Legalisasi Desa Tangguh Bencana. 


\section{DAFTAR PUSTAKA}

Thomas D. Schneid, and Larry Collins. (2001). Disaster Management Preparedness. New York: Lewis Publisher

Jon Ingleton (Editor). (2000). Natural Disaster Management. England: Tudor Rose

Khambali. (2017). Manajemen Penanggulangan Bencana. Yogyakarta: Andi Publisher

Badan Nasional Penanggulangan Bencana. (2012). Pedoman Sistem Peringatan Dini Berbasis Masyarakat. http://www.bnpb.go.id.

Badan Nasional Penanggulangan Bencana. Rencana Nasional Penanganan Bencana 2010-2014. Jakarta; 2009.

Indonesia. Undang-Undang RI No.24 Tahun 2007. Penanggulangan Bencana: Jakarta; 2007

Badan Nasional Penanggulangan Bencana. Indeks Rawan Bencana Indonesia. Jakarta: BNPB. Jakarta; 2011.

Pan American Health Organization. Bencana Alam Perlindungan Kesehatan Masyarakat. Jakarta: EGC; 2006. 